\title{
The C264Y Missense Mutation in the Extracellular Domain of L1 Impairs Protein Trafficking In Vitro and In Vivo
}

\author{
Annette E. Rünker, ${ }^{1}$ Udo Bartsch, ${ }^{1}$ Klaus-Armin Nave, ${ }^{2}$ and Melitta Schachner ${ }^{1}$ \\ ${ }^{1}$ Zentrum für Molekulare Neurobiologie, Universität Hamburg, D-20246 Hamburg, Germany, and ${ }^{2}$ Department of Neurogenetics, Max-Planck-Institute for \\ Experimental Medicine, D-37075 Göttingen, Germany
}

\begin{abstract}
The neural cell adhesion molecule L1, a member of the immunoglobulin superfamily, performs important functions in the developing and adult nervous system and is implicated in neuronal migration and survival, elongation, fasciculation and pathfinding of axons, and synaptic plasticity. This view is in line with the fact that mutations in the $\mathrm{L} 1$ gene result in severe neurological syndromes in humans. Patients with missense mutations in the extracellular domain of L1 often develop severe phenotypes. Here, we characterized in vitro and in vivo the missense mutation $\mathrm{C} 264 \mathrm{Y}$, which is located in the extracellular domain of L1 and causes a severe phenotype in humans. Transfection studies in vitro demonstrate that L1 carrying this missense mutation is not expressed at the cell surface but instead is located intracellularly, most likely within the endoplasmic reticulum. Lack of cell surface expression of L1 with a C264Y mutation was confirmed in a transgenic mouse line expressing the $\mathrm{C} 264 \mathrm{Y}$ mutation under the control of the L1 promoter in an L1-deficient background. Analysis of these transgenic mice indicates that they represent functional null mutants, phenotypically indistinguishable from L1-deficient mice. These observations corroborate the view that impaired cell surface expression of mutated variants of L1 is a potential explanation for the high number of severe pathogenic mutations identified within the human L1 gene.
\end{abstract}

Key words: L1; missense mutation; protein trafficking; transgenic mouse; human disease; adhesion molecule

\section{Introduction}

Mutations in the gene encoding the cell recognition molecule L1 cause severe neurological syndromes in humans, termed HSAS (hydrocephalus attributable to stenosis of the aqueduct of Sylvius), MASA (mental retardation, aphasia, shuffling gait, adducted thumbs), SP-1 (spastic paraplegia type-1), and ACC (agenesis of corpus callosum) (Fransen et al., 1995; Brümmendorf et al., 1998; Weller and Gartner, 2001). To date, $\sim 144$ different pathogenic mutations have been identified in virtually all regions of the gene (http://dnalab-www.uia.ac.be/dnalab/11/) (Van Camp et al., 1996). The severity of the disease varies significantly among patients with different L1 mutations and may also vary among patients carrying the same mutation. However, a certain correlation between the severity of the disease and the type and location of the mutation has been demonstrated (Bateman et al., 1996; Yamasaki et al., 1997; Fransen et al., 1998; Michaelis et al., 1998).

The severe and complex neurological phenotype of patients with L1 mutations is in line with the view that L1 performs various important functions during neural development. Specifically, the protein has been implicated in neuronal migration and survival, axonal elongation, fasciculation and pathfinding, myelination, and synaptic plasticity (Burden-Gulley et al., 1997). L1, a

\footnotetext{
Received May 20, 2002; revised 0ct. 18, 2002; accepted 0ct. 22, 2002.

We are grateful to Drs. Martin Bastmeyer and Pekka Kallunki for help with anterograde tracing of the corticospinal tract and for providing plasmids, respectively. We thank Tanja Stößner for animal care and Emmanuela Szpotowizz for preparation of ultrathin sections.

Correspondence should be addressed to Melitta Schachner, Zentrum für Molekulare Neurobiologie, Universität Hamburg, Martinistrasse 52, D-20246 Hamburg, Germany. E-mail: melitta.schachner@zmnh.uni-hamburg.de.

U. Bartsch's present address: Augenklinik, Transplantationslabor, Universität Hamburg, Martinistrasse 52, D-20246 Hamburg, Germany.

Copyright $\odot 2002$ Society for Neuroscience $\quad 0270-6474 / 02 / 220277-10 \$ 15.00 / 0$
}

member of the Ig superfamily consisting of six Ig-like and five fibronectin type III-like domains, a transmembrane domain, and a short cytoplasmic tail (Moos et al., 1988), exerts its functions mainly by homophilic interactions (Lemmon et al., 1989; Miura et al., 1992). However, the protein has also been shown to interact heterophilically with various ligands (Brümmendorf et al., 1998; Kenwrick et al., 2000). In addition to its adhesive properties, L1 is a signal-transducing receptor that interacts with several kinases and the cytoskeleton (Crossin and Krushel, 2000; Bennett and Chen, 2001).

Many of the pathological features observed in human patients with L1 mutations were also seen in mice with a targeted disruption of the L1 gene (Dahme et al., 1997; Cohen et al., 1998), and their analysis provided important insights into the functions performed by L1 in vivo (Dahme et al., 1997; Cohen et al., 1998; Demyanenko et al., 1999, 2001; Haney et al., 1999; Rolf et al., 2001). However, the reasons for the high number of different L1 missense mutations with severe consequences are only partly understood, and appropriate animals models for such conditions are still absent. Potentially, these mutations might interfere with homophilic or heterophilic interactions of L1 or with the targeting of the protein to the cell surface (De Angelis et al., 1999, 2002; Moulding et al., 2000).

Here, we performed a detailed characterization of the extracellularly located missense mutation C264Y, known to cause HSAS in humans (Jouet et al., 1993). We observed lack of cell surface expression of this mutated L1 variant in transfected Chinese hamster ovary $(\mathrm{CHO})$ cells in vitro and, more importantly, in a transgenic mouse line in vivo. These observations indicate that the L1C264Y mutation results in loss of function as a result of impaired protein trafficking, thus providing an explanation for its devastating effect in humans. Indeed, L1C264Y-transgenic 
mice displayed a phenotype indistinguishable from that of L1deficient mice.

\section{Materials and Methods}

Mutant L1 cDNA constructs. Four different mutant variants of murine L1 cDNA were constructed using the Seamless PCR cloning Kit (Stratagene, La Jolla, CA) according to the manufacturer's protocol: L1 lacking exon 2 (L1 $\Delta \mathrm{E} 2$; deletion of bp 77-91) or exon 27 (L1 $\Delta \mathrm{E} 27$; deletion of bp 3540 3551); L1 lacking the putative homophilic binding site of 14 amino acids from residue His177 to Gly190 (L1 $\Delta$ hbs; deletion of bp 529-570) (Zhao et al., 1998), and L1 containing the pathogenic point mutation C264Y (L1C264Y; G to A substitution of bp 788) (Jouet et al., 1993). In brief, the vector pGEM2-L1cDNA was amplified with primers flanking the region selected to introduce the deletions or the point mutation and was fused again. To obtain a construct encoding the short L1 isoform (sL1) lacking both, exon2 (15 bp) and 27 (12 bp), an EcoRI-BamHI fragment of pGEM2-L1 $\Delta$ ex 2 was cloned into pGEM2-L1 $\Delta$ ex 27. The isoform sL1 results from alternative splicing and is expressed in Schwann cells and some non-neural cell types (Takeda et al., 1996).

All L1 cDNA constructs, including wild-type L1 (L1wt), were cloned into the pcDNA3 mammalian expression vector and confirmed by DNA sequencing. In addition, the pCR3.uni-L1exHA (L1ex) containing the extracellular transmembrane and the first nine amino acids of the intracellular domain of L1 (aa 1-1152) in fusion with a hemagglutinin epitope-tag (kindly provided by P. Kallunki, The Scripps Research Institute, La Jolla, CA) (Kallunki et al., 1998) was used.

Generation of L1C264Y-transgenic mice. The L1lacZ vector, containing the $\mathrm{L} 1$ promoter, a lac $Z$ gene, and the neural restrictive silencer element sequence (kind gift from P. Kallunki) (Kallunki et al., 1997, 1998; Meech et al., 1999) was modified to generate a mouse line, expressing the pathogenic point mutation L1C264Y under the control of the L1 promoter. An EcoRI-PvuI fragment of pcDNA3-L1C264Y containing the mouse L1 cDNA with the C264Y point mutation was initially cloned into the EcoRI-opened vector pBlueCAM-SK(+). The lacZ gene was removed from vector L1lacZ by digestion with NotI and XhoI and replaced with L1C264Y. The $22 \mathrm{~kb}$ transgenic construct was excised from the plasmid by digestion with $P v u$ I and SnaBI and microinjected into DBA-C57BL/6J hybrid zygotes using standard techniques (Hogan et al., 1994). Founder mice were identified by PCR. The F1 generation of five founders was crossed with heterozygous L1 knock-out $(\mathrm{L} 1+/-$ ) females (Dahme et al., 1997) to obtain male double mutants (L1-/y_C264Y, further termed L1C264Y) with an expression of the L1C264Y transgene in an L1deficient background. Transgenic males of two founder lines with the highest level of transgene expression (see below) were further mated with heterozygous L1 knock-in females (L1-deficient mice, generated by insertion of thymidine kinase and neomycine-resistance genes into the ninth exon of the L1 gene; 129/SvJ-F6) (Rolf et al., 2001). Animals from the second to fifth generation of such crosses were used for analysis.

Cell culture and transfection. $\mathrm{CHO}$ cells were maintained in Glasgow modified Eagle's medium supplemented with $10 \%$ fetal calf serum. CHO cells were transfected with plasmids encoding L1wt, sL1, L1ex, L1 $\Delta \mathrm{hbs}$, or L1C264Y using the Lipofectamine Plus kit (Invitrogen, Gaithersburg, $\mathrm{MD}$ ) according to the manufacturer's instructions and maintained for an additional 36,48 , or $72 \mathrm{hr}$ in culture. To obtain stably transfected cells, CHO cells were transfected with L1wt, L1 ex, L1 $\Delta$ hbs, or L1 C264Y cDNA and selected with G418 ( $800 \mu \mathrm{g} / \mathrm{ml}$ for selection, $300 \mu \mathrm{g} / \mathrm{ml}$ for maintenance). Cells transfected with the empty pcDNA3 vector (mock) served as a control.

Indirect immunofluorescence staining of fixed and live cells. $\mathrm{CHO}$ cells were seeded on poly-L-lysine-coated coverslips $18 \mathrm{hr}$ after transfection. To investigate expression of L1 at the cell surface, live (i.e., nonpermeabilized) cells were incubated with rat monoclonal L1 antibodies (mAb555; undiluted supernatant) (Appel et al., 1995) at $4^{\circ} \mathrm{C}$ for $20 \mathrm{~min}$. This antibody recognizes an epitope at the border between the second and third fibronectin-like domain. Primary antibodies were detected with Cy3-conjugated anti-rat IgG (1:500; Dianova, Hamburg, Germany). To examine localization of $\mathrm{L} 1$ in permeabilized cells, fixation with $4 \%$ paraformaldehyde in PBS was performed before incubation with primary antibodies. Cells were analyzed using an Axiophot (Zeiss,
Oberkochen, Germany). Stably transfected CHO cells were immunostained in suspension as live cells as described above. Flow cytometric analysis was performed using a FACS Calibur System (Becton Dickinson, Heidelberg, Germany).

Immunohistochemistry. Vibratome sections, $25 \mu \mathrm{m}$ in thickness, were prepared from perfusion-fixed brains, blocked in PBS, $\mathrm{pH}$ 7.4, containing $1 \%$ bovine serum albumin and $0.5 \%$ Triton X-100 for $1.5 \mathrm{hr}$, and incubated overnight at $4^{\circ} \mathrm{C}$ with polyclonal $\mathrm{L} 1$ antibodies (Faissner et al., 1985). Primary antibodies were visualized with Cy3-conjugated antirabbit IgG (1:500; Dianova), and sections were analyzed using an Axiophot (Zeiss).

Immunoblot analysis. Stably or transiently transfected cells were lysed in RIPA buffer [ $150 \mathrm{~mm} \mathrm{NaCl}, 50$ mm Tris-HCl, pH 7.4, 1 mм EDTA, 1\% NP-40, $1 \times$ complete protease inhibitor mixture (Roche Diagnostics, Mannheim, Germany)]. Lysates were cleared by centrifugation at $12,000 \times g$ for $10 \mathrm{~min}$ at $4^{\circ} \mathrm{C}$. The brains of embryonic ( $17.5 \mathrm{~d}$ old; $n=2$ for each genotype) or adult ( 3 months old; $n=2$ per genotype) mice were homogenized in lysis buffer (20 mм Tris- $\mathrm{HCl}, \mathrm{pH} 7.5,150 \mathrm{~mm} \mathrm{NaCl}, 1$ mM EDTA, 1 mm EGTA, 1\% NP-40, $1 \times$ complete protease inhibitor mixture) and incubated for $30 \mathrm{~min}$ at $4^{\circ} \mathrm{C}$. The homogenates were cleared by centrifugation three times at $12,000 \times g$ for $20 \mathrm{~min}$ at $4^{\circ} \mathrm{C}$. The protein concentrations of lysates and homogenates were determined using the BCA protein assay kit (Pierce, Rockford, IL). The probes were denatured in $5 \times$ sample buffer ( $10 \%$ glycerol, $5 \% \beta$-mercaptoethanol, $5 \%$ SDS, $0.1 \%$ bromophenol blue) for $5 \mathrm{~min}$ at $95^{\circ} \mathrm{C}$ and subjected to SDS-PAGE and immunoblot analysis using monoclonal (mAb555; diluted 1:5) or polyclonal (diluted 1:8000) L1 antibodies. Primary antibodies were detected with HRP-conjugated anti-rat or anti-rabbit IgG and visualized with ECL (Pierce).

Biotinylation of cell surface proteins. CHO cells, 48 and $72 \mathrm{hr}$ after transfection, were kept on ice during the entire biotinylation procedure. Cells were washed for $5 \mathrm{~min}$ with PBS containing $0.5 \mathrm{mM} \mathrm{CaCl}_{2}$ and $2 \mathrm{mM}$ $\mathrm{MgCl}_{2}\left(\mathrm{PBS}^{2+}\right)$ and incubated for $10 \mathrm{~min}$ with $\mathrm{PBS}^{2+}$ containing $0.5 \mathrm{mg} / \mathrm{ml}$ sulfo- $N$-hydroxysuccinimide-disulfide-biotin (Pierce). For quenching, the cells were washed for $5 \mathrm{~min}$ in $\mathrm{PBS}^{2+}$ containing $20 \mathrm{~mm}$ glycine, further washed with $\mathrm{PBS}^{2+}$, and lysed in RIPA buffer (see above). For extraction of biotinylated proteins, the lysates were rotation incubated with 50\% streptavidin-agarose (in RIPA buffer) overnight at $4^{\circ} \mathrm{C}$. After washing, the pelleted agarose-protein complex was resuspended in sample buffer (containing $5 \%$ fresh $\beta$-mercaptoethanol) and denatured at $95^{\circ} \mathrm{C}$ for $5 \mathrm{~min}$. The supernatant was subjected to immunoblot analysis.

Deglycosylation with endoglycosidase $H$. For deglycosylation of proteins, cell lysates of $\mathrm{CHO}$ cells $72 \mathrm{hr}$ after transient transfection and brain homogenates of 17.5-d-old mouse embryos or 3-month-old mice were prepared as described above. The denatured lysates (10 $\mu \mathrm{g}$ of cell lysates, $20 \mu \mathrm{g}$ of brain homogenates) were incubated overnight at $37^{\circ} \mathrm{C}$ in $75 \mathrm{~mm}$ sodium citrate, $\mathrm{pH} 5.5$, and $1 \times$ complete protease inhibitor mixture with or without $0.5 \mathrm{mU}$ endoglycosidase $\mathrm{H}$ (endo H) (Roche Diagnostics).

Tracing of the corticospinal tract. Three injections of the lipophilic fluorescent dye 1,1'-dioctadecyl-3,3,3',3'-tetramethylindocarbocyanine perchlorate [dissolved in dimethylformamide (Sigma, Deisenhofen, Germany)] were made unilaterally into the motor cortex of deeply anesthetized mice at postnatal day (P) 1 or 2 using a Multi-Channel Picospritzer (General Valve, Fairfield, NJ). After 1-2 d (at P3-4), brains were removed and fixed by immersion in PBS containing 4\% paraformaldehyde for 3-5 d. Frontal vibratome sections, $50 \mu \mathrm{m}$ in thickness, were prepared starting at rostral levels of the medulla and ending at cervical levels of the spinal cord.

Light and electron microscopy. Mice (70- to 75-d-old) were perfused with PBS containing 4\% paraformaldehyde and 3\% glutaraldehyde. Frontal vibratome sections of the brainstem, $400 \mu \mathrm{m}$ in thickness, and sciatic nerves were embedded in Epon resin. For light microscopic analysis of the corticospinal tract (CST), semithin sections, $4 \mu \mathrm{m}$ thick, were prepared from caudal levels of the medulla and stained with $0.1 \%$ toluidine blue and $0.1 \%$ methylene blue in $4 \% \mathrm{Na}_{2} \mathrm{CO}_{3}$. The area of the CST was measured at caudal levels of the medulla immediately rostral to the pyramidal decussation using a computer-assisted image analysis system (Neurolucida, Microbrightfield, Colchester, UK). For electron micro- 
scopic analysis of the peripheral nervous system, ultrathin sections were prepared from sciatic nerves and stained with lead citrate. Micrographs from randomly selected unmyelinated fibers were taken at a magnification of $8000 \times$ with a Zeiss EM10 electron microscope. For each animal, 25-35 unmyelinated fibers were analyzed.

\section{Results \\ The cell surface localization of $\mathrm{L} 1 \Delta \mathrm{hbs}$ and $\mathrm{L} 1 \mathrm{C} 264 \mathrm{Y}$ is strongly reduced}

The localization of L1wt, sL1 (short L1 isoform), L1ex (deletion of the cytoplasmic domain), L1 $\Delta$ hbs (deletion of the putative 14 aa homophilic binding site) (Zhao et al., 1998), and L1C264Y (human pathogenic missense mutation) (Jouet et al., 1993) on the surface of $\mathrm{CHO}$ cells was investigated by indirect immunofluorescence staining of live cells 36,48 , and $72 \mathrm{hr}$ after transfection with the different constructs (Fig. $1 a-f$ ). A high percentage of L1-immunopositive cells $(\sim 70-80 \%)$ was found in cultures $36 \mathrm{hr}$ after transfection with L1wt (Fig. 1a) and L1ex (Fig. 1c). Cultures transfected with sL1 contained slightly fewer immunoreactive cells (Fig. 1b). In contrast, the percentage of $\mathrm{CHO}$ cells expressing L1 $\Delta$ hbs (Fig. 1d) and L1C264Y (Fig. 1e) was very low ( 10-20\%), particularly for L1C264Y-transfected cultures. The variability in labeling intensity of L1wt-, sL1-, and L1extransfected cells was very broad, ranging from weakly to intensely stained cells. In comparison, only strongly labeled cells were found in cultures transfected with L1 $1 \mathrm{hbs}$ and L1C264Y.

L1 indirect immunofluorescence of nonpermeabilized cells 48 and $72 \mathrm{hr}$ after transfection showed a strong decrease in the number of L1 $\Delta$ hbs- and L1C264Y-immunopositive cells when compared with cultures transfected with L1wt, sL1, or L1ex (data not shown). In fact, in L1C264Y-transfected cultures, labeled cells were virtually absent $72 \mathrm{hr}$ after transfection.

For analysis of long-term expression, $\mathrm{CHO}$ cells were stably transfected with L1wt, L1ex, L1 1 hbs, and L1C264Y. For each construct, six clones were stained as live cells with anti-L1 antibodies and analyzed by FACS to determine the number of positive cells. The percentage of L1-positive cells in the clonal cultures was estimated for all L1 mutations and related to L1wt (set to $100 \pm 9.7 \%$ ) (Fig. $1 \mathrm{~g}$ ). The percentage of cells expressing L1ex on their surface $(88.6 \pm 30.0 \%)$ was similar to that of L1wt-positive cells. In contrast, only $9.5 \%( \pm 6.7 \%)$ of cells were labeled in L1 $\Delta$ hbs-transfected cultures. The percentage of positive cells in L1C264Y-transfected cultures $(3.5 \pm 1.3 \%)$ was in the range of mock-transfected cells $(3.0 \pm 0.8 \%)$.

The percentage of L1-immunoreactive cells in L1 $\Delta$ hbs- or L1C264Y-transfected cultures was clearly increased when cells were permeabilized before immunostaining (data not shown). Qualitative inspection of permeabilized L1 $\Delta$ hbs- or L1C264Ytransfected cultures with L1wt-transfected cultures revealed a similar percentage of L1-immunoreactive cells with a similar variability in fluorescence intensity between cells of each culture. This observation was supported by similar expression levels of L1 in cultures transfected with L1wt and L1 variants as revealed by immunoblot analysis (see below) and argues against the possibility that the low number of L1 $\Delta$ hbs- or L1C264Y-transfected cells with cell surface expression of L1 is caused by low expression levels or a poor transfection efficiency.

\section{$\mathrm{L} 1 \Delta \mathrm{hbs}$ and $\mathrm{L} 1 \mathrm{C} 264 \mathrm{Y}$ are expressed as a protein variant with} a reduced molecular weight

To further analyze the expression levels and post-translational modifications of the different L1 mutations, CHO cells were subjected to immunoblot analysis (Figs. 2, 3b,e). At all time points
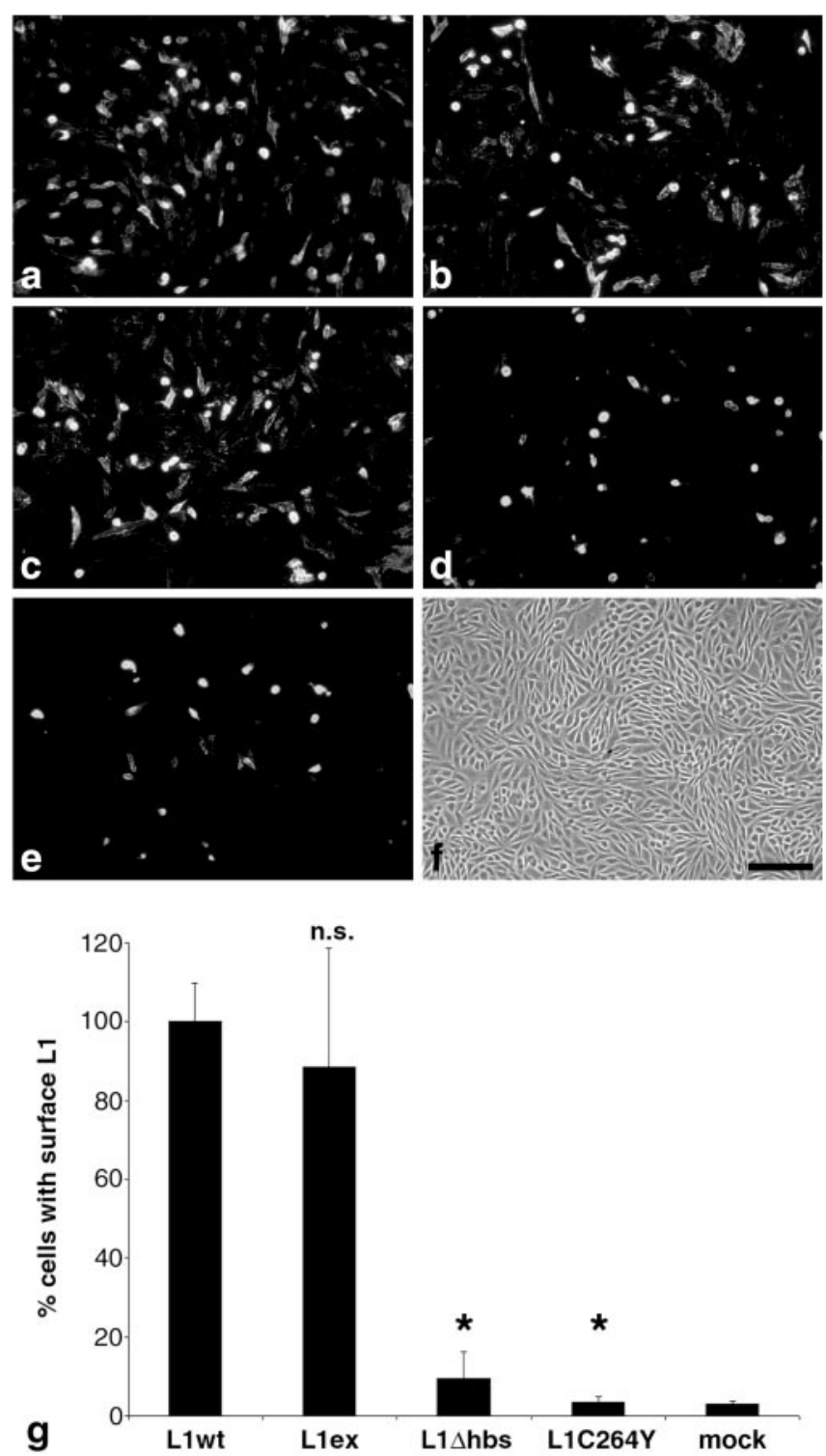

Figure 1. $a-e$, Indirect L1-immunofluorescence staining of live $\mathrm{CHO}$ cells $36 \mathrm{hr}$ after transient transfection with L1wt $(a)$, sL1 (b), L1ex (c), L1 $\Delta$ hbs ( $d$ ), and L1C264Y (e; fis the phasecontrast photomicrograph of e) using mAb555. Most of the cells in cultures transfected with L1wt (a), SL1 (b), and L1ex (c) are labeled by L1 antibodies. In contrast, only a few L1-positive cells are detectable in cultures transfected with L1 $\Delta$ hbs $(d)$ or L1C264Y (e). g, CHO cells were stably transfected with L1wt, L1ex, L1 $\Delta \mathrm{hbs}$, and L1C264Y, and the percentage of cells expressing $\mathrm{L} 1$ on their surface was determined using FACS (the percentage of L1-immunoreactive cells in cultures transfected with L1wt was set to $100 \%$ ). A similar percentage of cells with surface expression of $\mathrm{L} 1$ is present in cultures transfected with L1wt and L1ex. In comparison, L1-positive cells are hardly detectable in cultures transfected with L1 $\Delta$ hbs or L1C264Y. Mock-transfected $\mathrm{CHO}$ cells served as a negative control. Error bars represent mean values \pm SD of six independent experiments for each construct. n.s., Not significantly different from L1wt; ${ }^{*}$, significantly different from L1wt ( $p<0.01$; Mann-Whitney test). Scale bar (shown in $f$ ): $a-f, 100 \mu \mathrm{m}$.

after transient transfection $(36,48$, and $72 \mathrm{hr}$ ), total lysates of these cultures contained similar amounts of L1 protein, for the different mutations and L1wt. This observation argues against different L1 expression levels or transfection efficiencies as a reason for differences in cell surface localization of the different L1 variants. Thirty-six hours after transfection (Fig. $2 a$ ), two bands of 220 and $190 \mathrm{kDa}$, characteristic for L1 expressed in cell culture, were identified for L1wt and all L1 mutations. For the L1ex mu- 


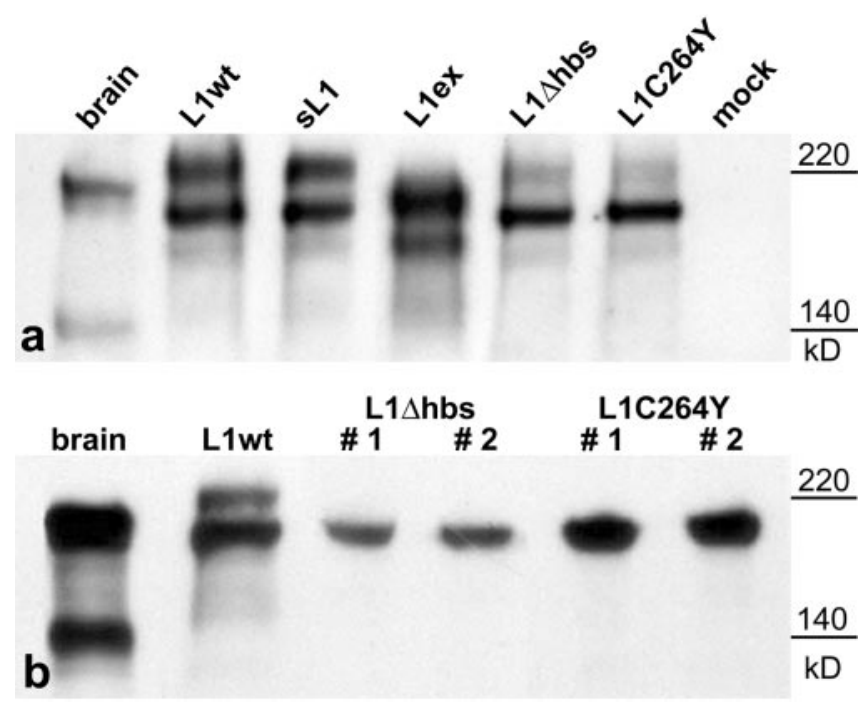

Figure 2. L1-immunoblot analysis of transiently ( $a$ ) (36 hr after transfection) and stably ( $b$ ) transfected $\mathrm{CHO}$ cells. L1-immunoreactive bands at 220 and $190 \mathrm{kDa}$ are detectable in cultures transfected with L1wt, sL1, and L1ex (a). The reduced molecular weight of L1 in cells transfected with $L 1$ ex is related to lack of the intracellular domain. In cultures transiently transfected with $\mathrm{L} 1 \Delta \mathrm{hbs}$ or L1C264Y (a), the $190 \mathrm{KDa}$ form of $\mathrm{L} 1$ is strongly expressed, whereas the $220 \mathrm{KDa}$ form is hardly detectable. $b$, The 220 and $190 \mathrm{kDa}$ forms of $\mathrm{L} 1$ are expressed in cultures stably transfected with L1wt $(b)$, whereas only the $190 \mathrm{kDa}$ band is detectable in cultures stably transfected with L1 $\Delta$ hbs or L1C264Y [shown are results from two (\#1 and \#2) of eight independent experiments for each construct]. Immunoblot analysis in $a$ and $b$ was performed with the L1 antibody mAb555, and mouse brain homogenates were included as an internal positive control. Mock-transfected $\mathrm{CHO}$ cells served as a negative control ( $a)$.

tation, both bands had a reduced molecular weight $(\sim 200$ and $170 \mathrm{kDa}$ ) caused by the lack of the intracellular domain. The upper $220 \mathrm{kDa}$ band corresponds to the full-length and fully glycosylated form of L1 located at the cell surface (Zisch et al., 1997). In cultures transfected with L1wt, sL1, and L1ex, the 220 $\mathrm{kDa}$ band had the same intensity as the $190 \mathrm{kDa}$ band. In contrast, in L1 $\Delta$ hbs- and L1C264Y-transfected cultures, the $220 \mathrm{kDa}$ signal was much weaker than the $190 \mathrm{kDa}$ band. After longer times post-transfection (Fig. 3b, $48 \mathrm{hr}$; Fig. $3 e, 72 \mathrm{hr}$ ), the ratio between the 220 and $190 \mathrm{kDa}$ band shifted slightly in favor of the lower one for all constructs. As a result, the $220 \mathrm{kDa}$ band was very faint in L1 $\Delta$ hbs-transfected cultures and almost absent in L1C264Ytransfected cultures $72 \mathrm{hr}$ after transfection.

Similar results were obtained for CHO cells stably transfected with L1wt, L1 $\Delta$ hbs, L1C264Y (Fig. 2b), and L1ex (data not shown). Both the 220 and the $190 \mathrm{kDa}$ band were present in lysates of L1wt- and L1ex-transfected cells, with a stronger signal for the lower band. In L1 $\Delta$ hbs- and L1C264Y-transfected cultures, only a single band at $190 \mathrm{kDa}$ was detectable.

\section{$\mathrm{L} 1 \Delta \mathrm{hbs}$ and L1C264Y are not located at the cell surface, but intracellularly}

The mutations L1 $\Delta$ hbs and L1C264Y showed a decrease in cell surface location and in the amount of the $220 \mathrm{kDa}$ form with increasing time intervals after transfection. Therefore, it is conceivable that the $190 \mathrm{kDa}$ band represents a protein not expressed at the cell surface. To investigate this hypothesis, proteins on the cell surface of transfected CHO cells were biotinylated 48 and 72 $\mathrm{hr}$ after transfection. The biotinylated proteins were extracted and analyzed by L1 immunoblotting (Fig. $3 a, d ; b$ and $e$ show whole-cell lysates before extraction of biotinylated proteins). The intensity of the $220 \mathrm{kDa}$ band was measured and related to L1wt
(100\%) (Fig. 3c,f). Cells transfected with sL1 (48 hr, 89.2\%; $72 \mathrm{hr}$, $92.6 \%)$ and L1ex (48 hr, 84.6\%; $72 \mathrm{hr}, 105.1 \%)$ expressed similar amounts of the $220 \mathrm{kDa}$ form of $\mathrm{L} 1$ at the cell surface. In comparison, levels of cell surface-associated L1 were significantly reduced $48 \mathrm{hr}$ (45.0 and 20.4\%) and $72 \mathrm{hr}$ (20.4 and 8.5\%) after transfection in L1 $\Delta$ hbs- and L1C264Y-transfected cultures, respectively. Thus, for these two mutations, a decrease in L1 expression of $\sim 50 \%$ was observed between the two time points investigated. This finding fits well with the decline in the number of L1-immunopositive live cells with time after transfection.

The major protein form detectable on the cell surface as revealed by biotinylation of live cells was the $220 \mathrm{kDa}$ form of L1 (Fig. 3a,d). In addition, a faint $160 \mathrm{kDa}$ band was found, most probably corresponding to the $140 \mathrm{kDa}$ proteolytic cleavage fragment of L1 normally observed in mouse brain. The broad band at $220 \mathrm{kDa}$ might contain an additional band, known as the $180 \mathrm{kDa}$ proteolytic fragment of L1 from mouse brain (Sadoul et al., 1988, 1989), which should appear in this cell line at $\sim 200 \mathrm{kDa}$. In contrast, the $190 \mathrm{kDa}$ protein form, present in lysates of $\mathrm{CHO}$ cells transfected with L1wt and the different L1 variants, was not labeled at the cell surface, indicating that it is not transported to the plasma membrane but is located inside the cell.

The most likely explanation for the reduced molecular weight of the L1 $1 \Delta$ hbs and L1C264Y variants of L1 is a change in glycosylation, probably resulting from impaired protein transport through the cell. To investigate this hypothesis, $\mathrm{CHO}$ cells were lysated $72 \mathrm{hr}$ after transfection, and the protein was digested with endo H (Fig. 3g). The enzyme removes glycans with terminal mannose residues, characteristic for glycoproteins located in the endoplasmic reticulum and early cis-Golgi apparatus during oligosaccharide processing (for review, see Parodi, 2000; Helenius and Aebi, 2001). After endo $\mathrm{H}$ treatment, the $190 \mathrm{kDa}$ protein form of $\mathrm{L} 1 \Delta \mathrm{hbs}$ and $\mathrm{L} 1 \mathrm{C} 264 \mathrm{Y}$ shifted to a $150 \mathrm{kDa}$ band, the estimated molecular weight of deglycosylated L1. The same shift in the molecular weight of the $190 \mathrm{kDa}$ band was observed in cultures transfected with L1wt, sL1, and L1ex. The reduced band intensities of endo $\mathrm{H}$-treated proteins compared with nontreated proteins might be related to a reduced reactivity of the antibody with the deglycosylated L1 protein or to a reduced stability of deglycosylated L1. In any case, our results demonstrate that the $190 \mathrm{kDa}$ form of L1 has undergone a complete cleavage of its glycans by endo $\mathrm{H}$ and thus indicate that it had entered the endoplasmic reticulum but had not been transported through the Golgi network to the cell surface.

\section{Generation of L1C264Y-transgenic mice}

Transgenic mice with an expression of L1C264Y under the control of the L1 promoter (Kallunki et al., 1998) were generated to establish an animal model for this pathogenic point mutation. PCR and Southern blot analysis identified five transgenic founders. To obtain mutant mice with expression of the transgene in an L1-deficient background, C57BL/6J transgenic males (L1+/y_C264Y) were bred with 129Sv/J heterozygous L1deficient females $(\mathrm{L} 1+/-)$ to produce L1-deficient L1C264Y transgenic males (L1-/y_C264Y, further termed L1C264Y). Subsequently, L1+/__C264Y females were mated with 129Sv/J wt males. The expression of transgenic L1C264Y was confirmed, and its amount was estimated by immunoblotting. Three founder lines showed no detectable expression of L1C264Y. Related to the level of the full-length $200 \mathrm{kDa}$ form of L1 and its $140 \mathrm{kDa}$ proteolytic fragment in wt mice, one founder line expressed $\sim 11 \%$ and another line $\sim 34 \%$ of the L1C264Y transgene. The founder 

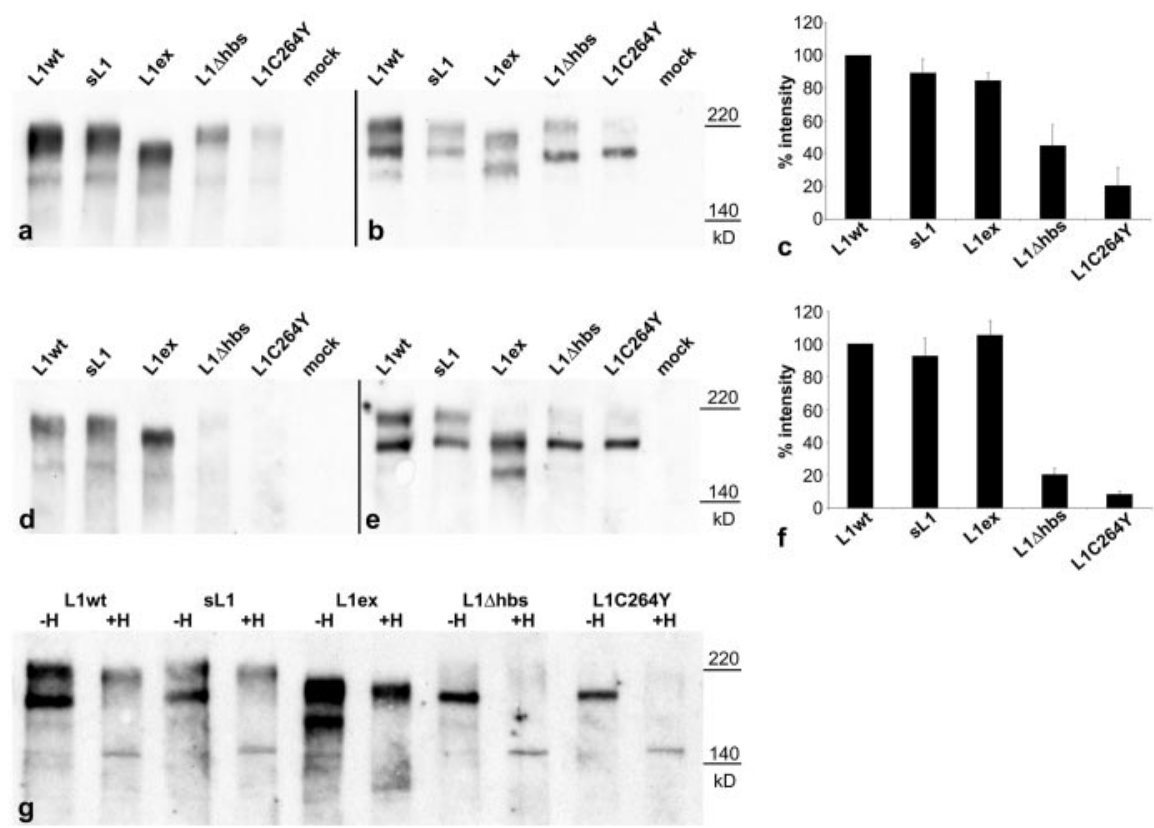

Figure 3. $a-f$, Extracted biotinylated cell surface proteins $(a, d)$ and whole-cell lysates $(b, e)$ from transiently transfected $\mathrm{CHO}$ cells $(a, b, 48 \mathrm{hr}$ after transfection; $d, e, 72 \mathrm{hr}$ after transfection) were subjected to $\mathrm{L} 1$-immunoblot analysis. Intensities of immunoreactive bands of biotinylated proteins were determined and related to $\mathrm{L} 1 \mathrm{wt}$ (set to $100 \%$ in each blot; $c, f$ ). Analysis of biotinylated proteins from CHO cells transfected with L1wt, sL1, and L1ex reveals a prominent band at $220 \mathrm{kDa}$ at both time points after transfection $(a, d)$. In cultures transfected with $\mathrm{L} 1 \Delta \mathrm{hbs}$ and $\mathrm{L} 1 \mathrm{C} 264 \mathrm{Y}$, in comparison, the $220 \mathrm{kDa}$ form of $\mathrm{L} 1$ is only weakly expressed $48 \mathrm{hr}$ after transfection $(a, c)$ and hardly detectable $72 \mathrm{hr}(d, f)$ after transfection. Note that the $190 \mathrm{kDa}$ form of $\mathrm{L} 1$ is absent from biotinylated protein extracts of all transfectants $(a, d)$. Note also the $\sim 50 \%$ decrease in the amount of cell surface-associated L1 in L1 $\Delta$ hbs-and L1C264Y-transfected cultures between 48 and $72 \mathrm{hr}$ after transfection (compare c, f). g, L1-immunoblot analysis of transiently transfected CHO cells ( $72 \mathrm{hr}$ after transfection) either without $(-\mathrm{H})$ or after $(+\mathrm{H})$ digestion with endo $\mathrm{H}$. Treatment with endo $\mathrm{H}$ does not alter the molecular weight of the $220 \mathrm{kDa}$ form of $\mathrm{L} 1$, whereas it reduces the molecular weight of the $190 \mathrm{kDa}$ form to $150 \mathrm{kDa}$. Error bars in c and frepresent the mean values $\pm S D$ of two independent experiments.

line with the highest level of L1C264Y expression was chosen for further investigations.

\section{L1C264Y expression is restricted to cell bodies of neurons}

Immunoblot analysis of brain tissue from 17.5-d-old L1C264Y mouse embryos revealed a single L1-immunoreactive band of $\sim 190 \mathrm{kDa}$ instead of the characteristic $200 \mathrm{kDa}$ (full-length) and $140 \mathrm{kDa}$ (proteolytic cleavage product) bands found in brain homogenates of wt mice (Fig. 4). Treatment of brain homogenates from L1C264Y males with endo $\mathrm{H}$ resulted in a shift of the $190 \mathrm{kDa}$ band to a $150 \mathrm{kDa}$ band (Fig. 4). Molecular weights of L1-immunoreactive bands in wt homogenates, in contrast, were not altered by endo $\mathrm{H}$ treatment (Fig. 4). This observation indicates that the $190 \mathrm{kDa}$ variant of L1 expressed in L1C264Y mice represents a not fully glycosylated protein. The same results were obtained with brain homogenates of 3-month-old mice (data not shown).

To study the expression of L1C264Y in brain tissue by immunohistochemistry, wild-type, L1C264Y, L1-/y, and L1+/y_C264Y mice were perfused, and $25-\mu \mathrm{m}$-thick vibratome sections of several regions of the CNS were stained with L1 antibodies (Fig. 5). In wt mice, intense and homogeneously distributed L1 immunoreactivity was observed in the molecular layer of the cerebellar cortex (Fig. 5a), in the fiber-rich layers of the hippocampus (alveus, and strata lacunosum moleculare, radiatum, and oriens) (Fig. $5 f, h, j$ ), in the nerve fiber layer and inner and outer plexiform layers of the retina, or in the molecular layer of the olfactory bulb (data not shown). In contrast, L1 immunostaining in L1C264Y mice was restricted to the somata of neurons normally extending
L1-positive processes, including Golgi, granule, basket, and stellate cells in the cerebellum (Fig. 5b,e); pyramidal cells (Fig. $5 g, i)$, granule cells, and hilar interneurons (Fig. $5 g, k$ ) in the hippocampus; ganglion, amacrine, and horizontal cells in the retina, and mitral cells in the olfactory bulb (data not shown). L1-immunopositive fibers were not detectable in the CNS of L1C264Y-transgenic mice. In L1+/y_C264Y mice, an intense L1 labeling of both fiber-rich regions and intracellularly labeled neuronal cell bodies was observed (Fig. 5d). Sections from L1-/y mice were L1 immunonegative (Fig. 5c).

\begin{abstract}
Abnormal phenotype of L1C264Y mice Our combined in vitro and in vivo data indicate that the pathogenic point mutation L1C264Y is not expressed at the cell surface. It is thus reasonable to assume that the L1C264Y-transgenic mouse is a functional knock-out mutant and exhibits a phenotype indistinguishable from that of L1-deficient mice. However, it is also possible that an accumulation of mutated L1 protein within the cell or a cell surface localization below detection levels results in a more severe or a milder phenotype, respectively. We therefore compared in detail the phenotypes of L1-/y and L1C264Y mice.
\end{abstract}

Both, L1-/y and L1C264Y mice had lacrimous and sunken eyes and difficulties using their hindlegs when hanging on a grid. The average body weight of 10 -week-old L1-/y (25.1 $\pm 2.6 \mathrm{gm} ; n=7)$ and L1C264Y mice (25.5 $\pm 1.5 \mathrm{gm}$; $n=7)$ was reduced when compared with wt (29.3 $\pm 1.6 \mathrm{gm} ; n=12$ ) and L1+/y_C264Y littermates $(28.6 \pm 1.2 \mathrm{gm} ; n=5)$. Survival until weaning was reduced in L1C264Y and L1-/y mice compared with wt mice. According to Mendelian frequencies, each of the four possible genotypes of males expected to derive from the given crosses should appear with a probability of $25 \%$. We used the number of wt males $(n=50)$ to calculate the percentage of males of the different genotypes that reached the age of weaning. According to these calculations, the frequency of L1+/y_C264Y mice was slightly lower $(21.2 \% ; n=42)$ than expected, whereas the number of L1C264Y and L1-/y mutants was dramatically and similarly reduced to $8.0 \%(n=16)$ and $9.5 \%(n=19)$, respectively.

Corticospinal axons of L1-deficient mice display pathfinding errors at the pyramidal decussation (Cohen et al., 1998). To evaluate whether similar abnormalities are detectable in L1C264Y mice, the CST of wt, L1-/y, and L1C264Y mice was anterogradely labeled at $\mathrm{P} 1$ or $\mathrm{P} 2$. The trajectory of the tract at the pyramidal decussation was analyzed $2 \mathrm{~d}$ after tracing (Fig. $6 a-f$ ). In wt mice $(n=5)$ (Fig. 6a,b), corticospinal axons turned dorsally at the caudal end of the medulla oblongata, crossed the midline, and extended into the contralateral dorsal column. In most L1-/y mice $(n=4)$, in contrast, a significant portion of axons failed to cross the midline and projected to the ipsilateral dorsal column (Fig. $6 c$ ). In other L1-/y mice, corticospinal axons turned ven- 


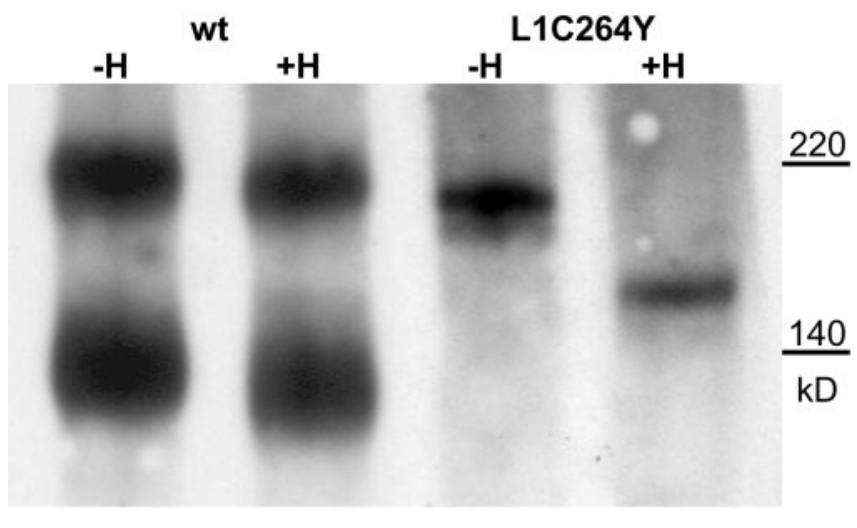

Figure 4. Brain homogenates from 17.5-d-old wt and L1C264Y-transgenic embryos were subjected to L1-immunoblot analysis either without $(-H)$ or after $(+H)$ digestion with endo H. In undigested samples, the characteristic L1-immunoreactive bands at 200 and $140 \mathrm{kDa}$ (a proteolytic cleavage product of $\mathrm{L} 1$ ) are detectable in wt mice. Brain homogenates from L1C264Y-transgenic mice, in comparison, contain a $190 \mathrm{kDa}$ instead of a $200 \mathrm{kDa}$ band and lack the $140 \mathrm{kDa}$ proteolytic cleavage product of L1. L1 protein from wt mice is insensitive to endo $\mathrm{H}$ treatment, whereas endo $\mathrm{H}$ digestion of brain homogenates from L1C264Y-transgenic mice results in a shift of the $190 \mathrm{kDa}$ band to $150 \mathrm{kDa}$.

trally and entered the contralateral pyramid $(n=2)$ (Fig. $6 d)$ or stayed ventral without crossing the midline $(n=1)$. Pathfinding errors of corticospinal axons were also observed at the pyramidal decussation of L1C264Y mice (Fig. 6e,f). Similar to L1-/y mice, a significant fraction of corticospinal axons projected to the ipsilateral dorsal column $(n=3)$ (Fig. 6e), or axons stayed ventral either without crossing the midline $(n=2)$ or extending into the contralateral pyramid $(n=2)$ (Fig. $6 f)$. One L1C264Y mutant displayed no obvious pathfinding errors at the pyramidal decussation.

The size of the CST is significantly reduced in L1-deficient mice (Dahme et al., 1997). Therefore, we determined the area of the CST in 10-week-old wt (Fig. 6g), L1-/y (Fig. 6h), L1C264Y (Fig. 6i), and L1+/y_C264Y mice at the caudal end of the medulla (Fig. 6j). The area of the CST of L1-/y mice was significantly reduced to $66.8 \%\left(56,264 \pm 7179 \mu \mathrm{m}^{2}\right.$ per tract; $\left.n=5\right)$ compared with wt mice $\left(84,199 \pm 7816 \mu \mathrm{m}^{2}\right.$ per tract; $\left.n=7\right)$. The CST of L1C264Y mice was reduced to a similar extent as that of L1-/y mice $\left(67.9 \% ; 57,133 \pm 7716 \mu \mathrm{m}^{2}\right.$ per tract; $\left.n=5\right)$, whereas the values for L1+/y_C264 mice (96.9\%; 81,572 $\pm 7043 \mu \mathrm{m}^{2}$; $n=3$ ) were not significantly different from that of wt animals.

Morphological abnormalities of unmyelinated fibers in peripheral nerves of L1-deficient mice include a reduced number of unmyelinated axons per nonmyelinating Schwann cell, Schwann cell processes extending into the endoneurial space, and the presence of incompletely ensheathed unmyelinated axons (Dahme et al., 1997; Haney et al., 1999). To investigate whether L1C264Y mice exhibit similar defects, we examined unmyelinated fibers in the sciatic nerve of 10- to 11-week-old wt, L1-/y, and L1C264Y mice. In wt animals, nonmyelinating Schwann cell processes ensheathed individual axons (Fig. 7a) whereas in both L1-/y (Fig. $7 b)$ and L1C264Y (Fig. $7 c)(n=6$ for each genotype) mutant mice a portion of axons were either incompletely or not ensheathed by Schwann cell processes. Instead, these axons were either covered by a basal lamina or in direct contact with each other (Fig. $7 b, c$ ). The percentage of axons with an incomplete (less than half of the axonal circumference) ensheathment by Schwann cell processes (Fig. 7d) was significantly increased to a similar extent in L1-/y $(22.5 \pm 3.6 \%)$ and L1C264Y $(26.7 \pm 4.4 \%)$ mice when compared with wt mice $(7.3 \pm 2.5 \%)$. Moreover, nonmyelinating Schwann
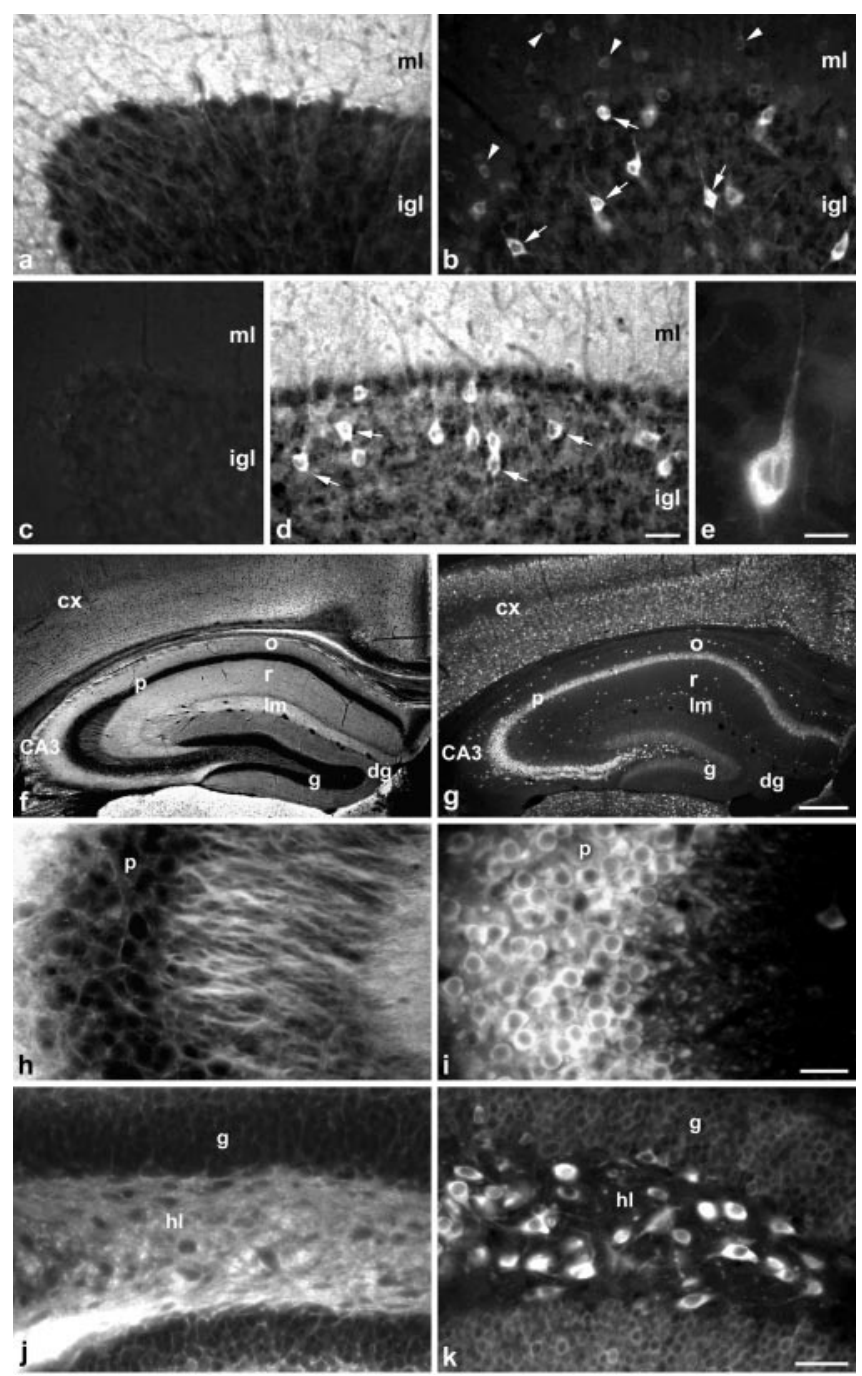

Figure 5. L1-immunohistochemistry of the cerebellum (a-e) and the hippocampus $(f-k)$ of 2-month-old wt $(a, f, h, j), \operatorname{L1C264Y}(b, e, g, i, k), \mathrm{L} 1-/ \mathrm{y}(c)$, and L1+/y_C264Y (d) mice. Intense and homogenously distributed $\mathrm{L} 1$ immunoreactivity is visible in fiber-rich brain regions of wt mice, including the molecular layer of the cerebellum $(a)$ or the strata oriens, radiatum, and lacunosum moleculare of the hippocampus $(f, h, j)$. Regions rich in cell bodies, such as the internal granular layer of the cerebellum $(a)$ or the pyramidal and granule cell layer of the hippocampus $(f, h, j)$, are only weakly $\mathrm{L} 1$ immunoreactive in wt mice. In contrast, L1-positive fibers are absent from the cerebellar cortex $(b)$ or the hippocampus ( $g, i, k$ ) of L1C264Y mice. Instead, intense intracellular labeling of Golgi cells (some labeled with arrows in $b ; e$ ) and weaker intracellular labeling of basket and stellate cells (some labeled with arrowheads in $b$ ) are visible in the cerebellar cortex of L1C264Y mice. In the hippocampus of these mutants, cell bodies of pyramidal cells $(i)$ and hilar interneurons $(k)$ are strongly stained by $L 1$ antibodies. Intracellular labeling is also visible for other nerve cell types, such as granule cells in the cerebellar cortex $(b)$ or dentate gyrus $(k)$. In L1+/y_C264Y mice, fiber tracts are homogeneously and nerve cell bodies intracellularly labeled by L1 antibodies ( $d$; some immunoreactive Golgi cells are labeled with arrows). Sections from L1-/y mice incubated with L1 antibodies were immunonegative ( $c) . c x$, Cortex; $d g$, dentate gyrus; $g$, granule cell layer; $h l$, hilus; igl, internal granule cell layer; $/ m$, stratum lacunosum moleculare; $m l$, molecular layer; 0 , stratum oriens; $p$ pyramidal cell layer; $r$, stratum radiatum. Scale bars: shown in $d$ for $a-d, 25 \mu \mathrm{m} ; e, 10 \mu \mathrm{m}$; shown in $g$ for $f$ and $g, 200 \mu \mathrm{m}$; shown in $i$ for $h$ and $i, 20 \mu \mathrm{m}$; shown in $k$ for $j$ and $k, 20 \mu \mathrm{m}$.

cells of both mutant mouse lines extended supernumerous processes into the endoneurial space (Fig. 7e). In wt mice, $8.2 \pm 4.2 \%$ of nonmyelinating Schwann cells extended such supernumerous processes into the endoneurium, compared with $73.4 \pm 7.8$ and $79.9 \pm 9.1 \%$ in L1-/y and L1C264Y mutants, respectively. Finally, the number of unmyelinated axons associated with 

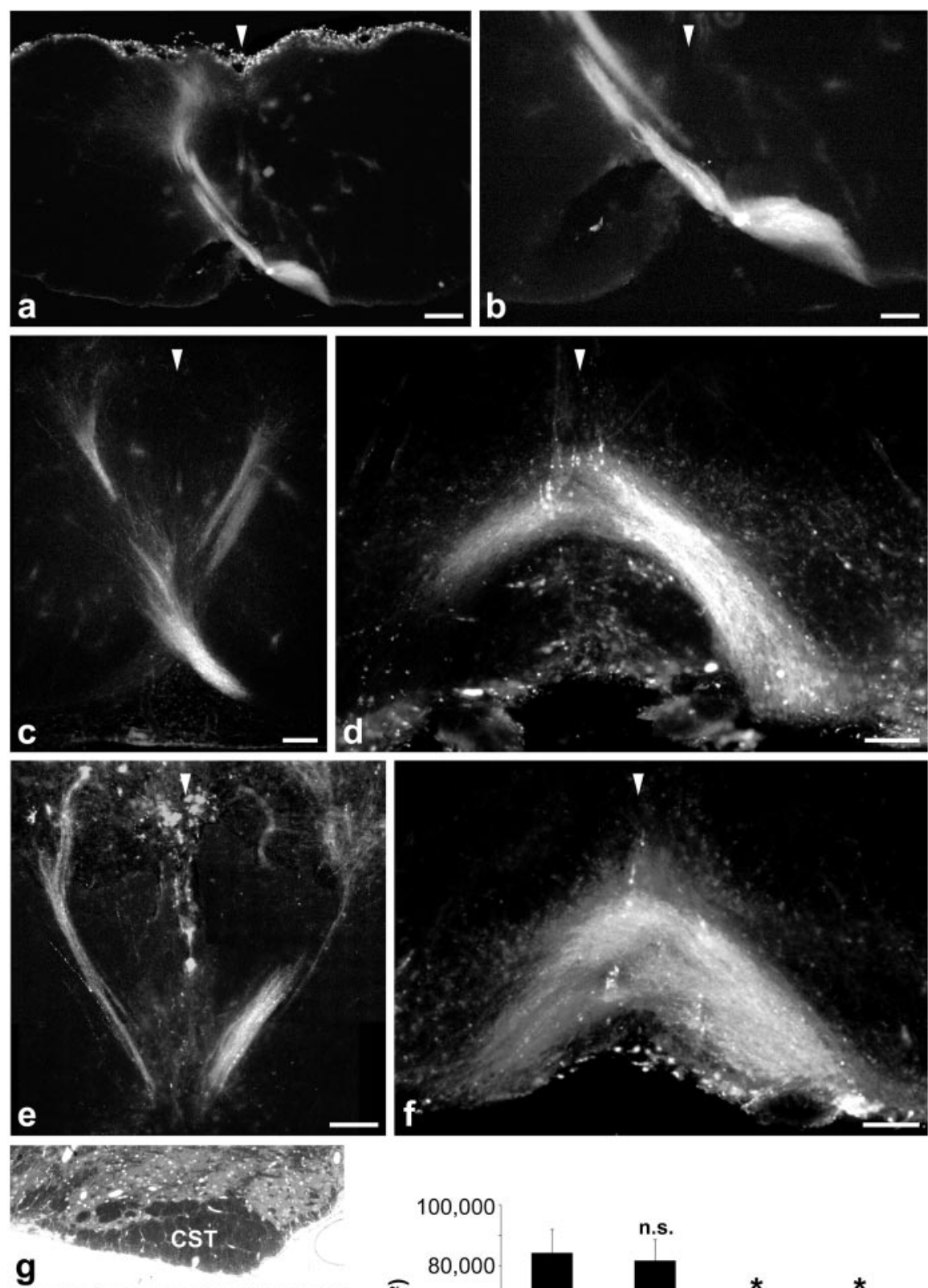

g
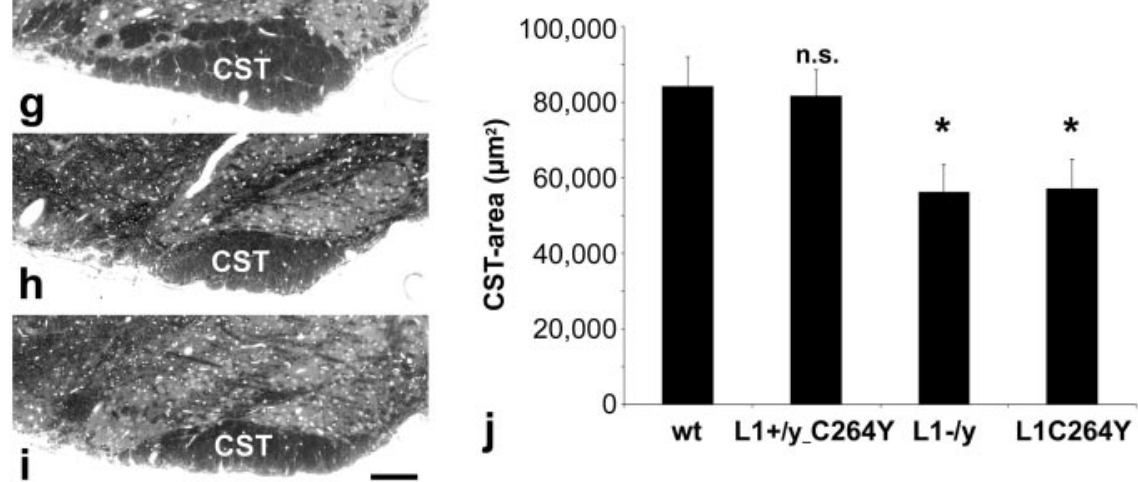

Figure 6. $a-f$, Anterograde tracing of corticospinal axons in wt $(a, b), \mathrm{L} 1-/ \mathrm{y}(c, d)$, and L1C264Y mice $(e, f)$, and analysis of their trajectory at the pyramidal decussation. In wt mice, corticospinal axons cross the midline (indicated by arrowheads in $a-f$ ) at the pyramidal decussation and extend to the dorsal column $(a, b)$. In L1-/y mice, corticospinal axons display pronounced pathfinding errors at the pyramidal decussation, and either project bilaterally to the dorsal column $(c)$ or cross the midline but stay ventral instead of projecting dorsally $(d)$. A bilateral projection of corticospinal axons to the dorsal column $(e)$ or a projection to the contralateral pyramid $(f)$ is also detectable in L1C264Y-transgenic mice. $g-j$, The size of the CST of L1-/y $(h)$ and L1C264Y mice $(i)$ is significantly reduced compared with wt mice $(g)$. Quantitative analysis $(j)$ reveals a similar size of the corticospinal tract (CST) in wt $(n=7)$ and L1+/y_C264Y $(n=3)$ mice. In comparison, the size of the CST is significantly reduced to a similar extent in L1-/y $(n=5)$ and L1C264Y ( $n=5)$ mice. Error bars in j represent mean values \pm SD. n.s., Not significantly different from wt; * , significantly different from wt ( $p<0.01$; Mann-Whitney test). Scale bars: $a, 200 \mu \mathrm{m} ; b-f, 100 \mu \mathrm{m}$; shown in ifor $g-i, 100 \mu \mathrm{m}$. one nonmyelinating Schwann cell was significantly and similarly reduced in L1-/y (9.0 \pm 1.9 axons per unit) and L1C264Y (9.9 \pm 2.0 axons per unit) compared with wt mice $(20.3 \pm 4.4$ axons per unit) (Fig. $7 f$ ).

\section{Discussion}

Mutations in all parts of the human L1 gene might cause a severe disease characterized by increased mortality, mental retardation, and various malformations of the nervous system (Fransen et al., 1995). In an attempt to understand the reasons for the frequent occurrence of severe missense mutations in the extracellular domain of L1, we studied the functional consequences of extracellular and cytoplasmic L1 mutations in vitro. To this aim, we used three mutated L1 constructs, L1ex, L1 $\Delta$ hbs, and L1C264Y, and studied their expression in $\mathrm{CHO}$ cells. Moreover, we generated transgenic mice expressing the extracellular missense mutation C264Y and analyzed the expression of this L1 variant in vivo and its effects on brain development. Our results demonstrate impaired trafficking of the mutated L1 variants $\mathrm{L} 1 \Delta \mathrm{hbs}$ and L1C264Y to the cell surface in vitro and of L1C264Y in vivo, resulting in the severe morphological deficits of the L1C264Ytransgenic mouse, indistinguishable from the deficits in L1-deficient mice.

When CHO cells were transiently transfected with L1C264Y and L1 $\Delta$ hbs, significantly reduced amounts of protein were found at the cell surface compared with L1wt, sL1, or L1ex. Cell surface levels of L1 $1 \Delta$ hbs and L1C264Y decreased further with increasing time after transfection. Furthermore, stably transfected $\mathrm{CHO}$ cells did not express detectable levels of the L1 $1 \Delta$ hbs and L1C264Y variants at their cell surface. Immunoblot analysis of total cell culture lysates revealed similar amounts of L1 protein for all L1 variants analyzed (i.e., L1wt, sL1, L1ex, L1 $\Delta$ hbs, and L1C264Y), demonstrating a similar transfection efficiency for all constructs. Although a prominent $220 \mathrm{kDa}$ band was observed in L1wt-, sL1-, and L1ex-transfected cells, such a band was very weak in short-term and absent in long-term cultures transfected with the L1 $\Delta$ hbs or L1C264Y constructs. Instead, for these two mutations, a $190 \mathrm{kDa}$ form of $\mathrm{L} 1$ was detected as the prominent L1immunoreactive band. This $190 \mathrm{kDa}$ form was not labeled in biotinylation experiments of live cells and was sensitive to endo $\mathrm{H}$ digestion, indicating intracel- 
lular localization and incomplete processing of the protein. This observation, together with the intracellular location of the $\mathrm{L} 1 \Delta \mathrm{hbs}$ and $\mathrm{L} 1 \mathrm{C} 264 \mathrm{Y}$ variants as revealed by indirect immunofluorescence staining of live cells, suggests retention of mutated L1 within the endoplasmic reticulum, most likely caused by a misfolding of the mutated proteins. For L1C264Y, such a misfolding is easily conceivable, because the cysteine residue is essential for the formation of a disulfide bridge in the third Ig-like domain of L1.

The extracellular pathogenic L1 missense mutations R184Q and D598N were also shown to be expressed at only very low levels at the cell surface and to be incompletely processed in cultured astrocytes, Vero, COS-7, and CHO cells for up to $24 \mathrm{hr}$ after infection (Moulding et al., 2000). In addition, reduced cell surface expression has recently been demonstrated for $\mathrm{CHO}$ and COS-7 cells for various extracellular missense mutations, including R184Q and C264Y (De Angelis et al., 2002). Low levels of cell surface expression of mutated L1 proteins described in these studies (Moulding et al., 2000; De Angelis et al., 2002) are in line with our observation of weak cell surface expression of L1 $\Delta$ hbs and L1C264Y in CHO cells in short-term transient transfection experiments. However, this weak cell surface expression disappeared after prolonged culture periods. We suggest that the early cell
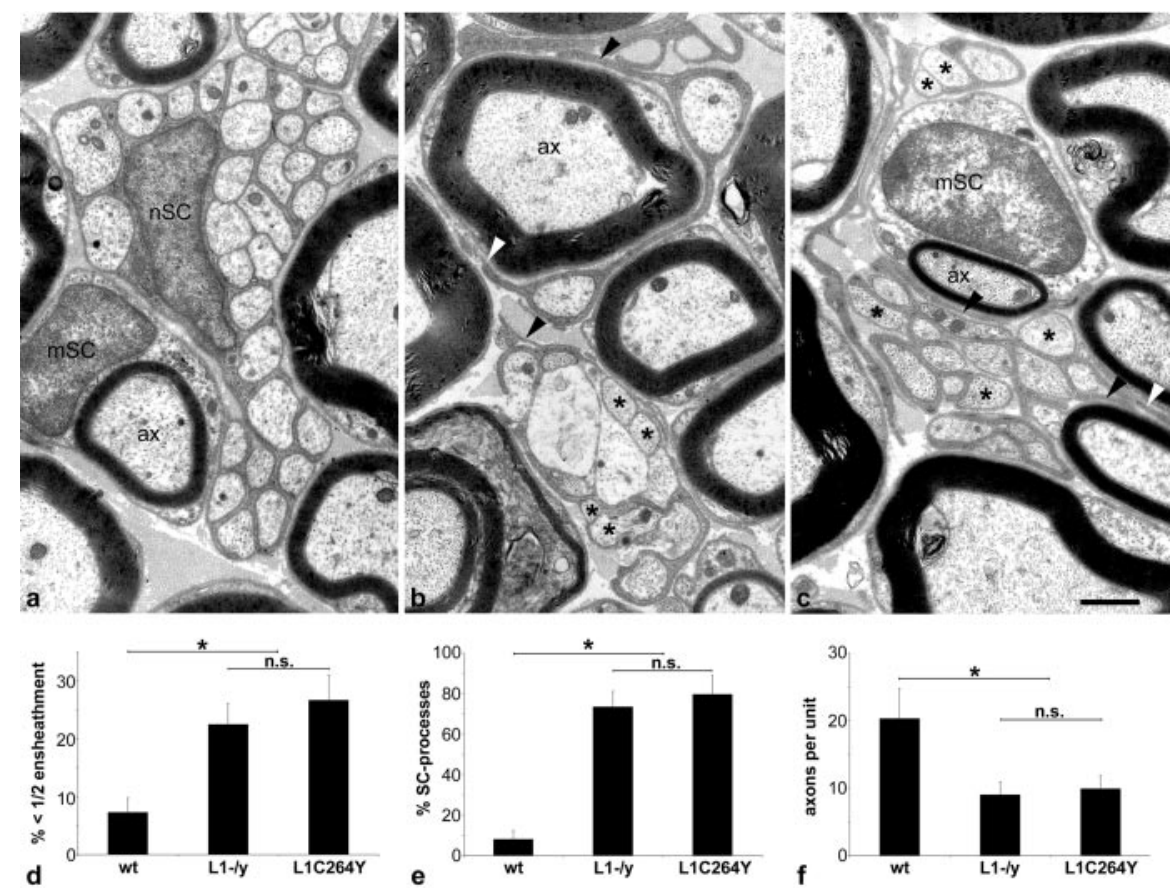

Figure 7. Ultrastructure of unmyelinated fibers in the sciatic nerve of wt (a), L1-/y (b), and L1C264Y (c) mice. Axons in wt ( $a$ ) mice are ensheathed and separated from each other by Schwann cell processes. In L1y/- $(b)$ and L1C264Y (c) mice, in contrast, a portion of axons (labeled with asterisks) is not covered by a Schwann cell process, and many nonmyelinating Schwann cells extend supernumerary processes (labeled with arrowheads) into the endoneurial space. Note also the reduced number of axons associated with one nonmyelinating Schwann cell in L1-/y $(b)$ and L1C264Y ( c ) mice compared with wt animals ( $a$ ). Quantitative analysis ( $d-f$ ) reveals a significant increase in the number of incompletely ensheathed axons per nonmyelinating $S c h w a n n$ cell $(d)$, a significant increase in the number of nonmyelinating Schwann cells extending one or more supernumerary processes into the endoneurium (e), and a significant decrease in the number of axons associated with one nonmyelinating Schwann cell ( $f$ ) in L1-/y and L1C264Y mice when compared with wt animals. Note that values for L1-/y and L1C264Y mice are not significantly different from each other for all parameters analyzed $(d-f)$. Error bars in $d-f$ represent mean values $\pm S D$ from six animals of each genotype. n.S., Not significantly different; * , significantly different ( $p<0.01$; Mann-Whitney test). ax, Myelinated axon; mSC, myelinating Schwann cell; $n S C$, nonmyelinating Schwann cell; SC-processes, Schwann cell processes. Scale bar (shown in c for $a-c): 1 \mu \mathrm{m}$.
The combined in vitro observations demonstrate that mutations in the extracellular domain of L1 can interfere with the targeting of the protein to the cell surface. These data are in line with a recent report demonstrating reduced L1 cell surface expression for various extracellularly located missense mutations (De Angelis et al., 2002), suggesting that many mutations in the extracellular domain of L1 might correspond to loss of function mutations. To evaluate whether such a mechanism is indeed the cause of the severe clinical picture of patients carrying the L1C264Y mutation (Jouet et al., 1993), we generated a transgenic mouse expressing this mutation under regulatory elements of the L1 gene (Kallunki et al., 1998). The transgenic animals were crossed into an L1-deficient background (Dahme et al., 1997; Rolf et al., 2001) to study expression of the transgene and its effects on brain development. In line with our observations in vitro, we found expression of an incompletely processed 190 $\mathrm{kDa}$ form of L1 by immunoblot analysis and an intracellular localization of the transgene by immunohistochemistry. Thus, L1C264Y-transgenic mice are likely to represent functional null mutants. Analysis of transgenic mice and L1-deficient animals indeed revealed similar phenotypes of both mutant mouse lines. Both L1C264Y-transgenic and L1-deficient animals were smaller in size, exhibited increased mortality, displayed hypoplasia of the CST and pathfinding errors of corticospinal axons at the pyramidal decussation, and showed impaired interactions between nonmyelinating Schwann cells likely to be important for correct folding of the protein, i.e., is not subject to the quality control within the endoplasmic reticulum.
Remarkably, mutation L1ex, which lacks most of the intracellular domain of L1, is expressed at similarly high levels at the cell surface of CHO cells as L1wt. Strong cell surface expression has also been reported for the intracellularly located pathogenic mutation S1 194L (Moulding et al., 2000). On the basis of these findings, we hypothesize that the intracellular domain of L1 is un- 
and axons in peripheral nerves (Dahme et al., 1997; Cohen et al., 1998; Haney et al., 1999).

The similar pathology of L1C264Y-transgenic and L1deficient mice allows suggestions about the fate of intracellularly located L1 mutant protein. In principle, there are two possibilities concerning the fate of misfolded proteins that are retained within the endoplasmic reticulum: either they might form undegradable aggregates that accumulate within the endoplasmic reticulum or they might be transported to the cytosol where they are degraded by proteasomes. The aggregation of proteins within the endoplasmic reticulum has been demonstrated in various human diseases to affect cell function or cell viability, including certain forms of $\alpha_{1}$-anti-trypsin deficiency (Wu et al., 1994; Mahadeva et al., 1998), Pelizaeus-Merzbacher disease (Schneider et al., 1994; Jung et al., 1996; Gow et al., 1998), or autosomal dominant retinitis pigmentosa (Olsson et al., 1992; Frederick et al., 2001). The underlying mutations act in a "dominant-negative" manner or exhibit a combination of loss- and gain-of-function effects. However, given the similarity between the phenotypes of L1C264Ytransgenic and L1-deficient mice, we consider a negative effect of intracellularly localized L1C264Y on cell viability or function as highly unlikely. Indeed, we have not observed an obvious decrease in the number of cells that normally would express L1 at the cell surface in the L1C264Y mutant in comparison with the L1-deficient mouse. We thus hypothesize that mutated L1 variants that are retained within the endoplasmic reticulum become degraded by proteasomes after release to the cytosol. Well studied examples of such a mechanism include cystic fibrosis (Ward and Kopito, 1994; Ward et al., 1995; Jensen et al., 1995), most forms of $\alpha 1$-anti-trypsin deficiency (Mahadeva et al., 1998), or CharcotMarie-Tooth disease caused by missense mutations in the connexin-32 gene (Bone et al., 1997; Deschenes et al., 1997; for review, see Bross et al., 1999).

In summary, we have confirmed and extended observations that demonstrate a reduction or lack of cell surface expression of mutated L1 variants in vitro (Moulding et al., 2000; De Angelis et al., 2002). More importantly, we have demonstrated for the first time that a pathogenic missense mutation of L1 results in lack of cell surface expression in vivo, causing a phenotype indistinguishable from that of the L1 null mutant. Thus, impaired trafficking of L1 to the cell surface, in addition to abnormal heterophilic and homophilic interactions of mutated L1 proteins (De Angelis et al., 1999; 2002) that reach the cell surface, potentially explains the high number of severe pathogenic mutations, particularly of those located within the extracellular domain of the protein. We suggest that the L1 mutant analyzed in the present study shows the usefulness of introducing human mutations into the mouse to elucidate the cellular and molecular mechanisms underlying the human L1 disease pathology. Whether this mutant could serve as an animal model closely related to human L1 diseases remains to be seen.

Note added in proof. A recent study also reports lack of cell surface expression of the C264Y mutation in stably transfected NIH-3T3 cells.

\section{References}

Appel F, Holm J, Conscience JF, von Bohlen und Halbach F, Faissner A, James P, Schachner M (1995) Identification of the border between fibronectin type III homologous repeats 2 and 3 of the neural cell adhesion molecule L1 as a neurite outgrowth promoting and signal transducing domain. J Neurobiol 28:297-312.

Bateman A, Jouet M, MacFarlane J, Du JS, Kenwrick S, Chothia C (1996) Outline structure of the human L1 cell adhesion molecule and the sites where mutations cause neurological disorders. EMBO J 15:6050-6059.
Bennett V, Chen L (2001) Ankyrins and cellular targeting of diverse membrane proteins to physiological sites. Curr Opin Cell Biol 13:61-67.

Bone LJ, Deschenes SM, Balice-Gordon RJ, Fischbeck KH, Scherer SS (1997) Connexin 32 and X-linked Charcot-Marie-Tooth disease. Neurobiol Dis 4:221-230.

Bross P, Corydon TJ, Andresen BS, Jorgensen MM, Bolund L, Gregersen N (1999) Protein misfolding and degradation in genetic diseases. Hum Mutat 14:186-198.

Brümmendorf T, Kenwrick S, Rathjen FG (1998) Neural cell recognition molecule L1: from cell biology to human hereditary brain malformations. Curr Opin Neurobiol 8:87-97.

Burden-Gulley SM, Pendergast M, Lemmon V (1997) The role of cell adhesion molecule L1 in axonal extension, growth cone motility, and signal transduction. Cell Tissue Res 290:415-422.

Cohen NR, Taylor JS, Scott LB, Guillery RW, Soriano P, Furley AJ (1998) Errors in corticospinal axon guidance in mice lacking the neural cell adhesion molecule L1. Curr Biol 8:26-33.

Crossin KL, Krushel LA (2000) Cellular signaling by neural cell adhesion molecules of the immunoglobulin superfamily. Dev Dyn 218:260-279.

Dahme M, Bartsch U, Martini R, Anliker B, Schachner M, Mantei N (1997) Disruption of the mouse L1 gene leads to malformations of the nervous system. Nat Genet 17:346-349.

De Angelis E, MacFarlane J, Du JS, Yeo G, Hicks R, Rathjen FG, Kenwrick S, Brummendorf T (1999) Pathological missense mutations of neural cell adhesion molecule L1 affect homophilic and heterophilic binding activities. EMBO J 18:4744-4753.

De Angelis E, Watkins A, Schafer M, Brummendorf T, Kenwrick S (2002) Disease-associated mutations in L1 CAM interfere with ligand interactions and cell-surface expression. Hum Mol Genet 11:1-12.

Demyanenko GP, Tsai AY, Maness PF (1999) Abnormalities in neuronal process extension, hippocampal development, and the ventricular system of L1 knock-out mice. J Neurosci 19:4907-4920.

Demyanenko GP, Shibata Y, Maness PF (2001) Altered distribution of dopaminergic neurons in the brain of L1 null mice. Dev Brain Res 126:21-30.

Deschenes SM, Walcott JL, Wexler TL, Scherer SS, Fischbeck KH (1997) Altered trafficking of mutant connexin32. J Neurosci 17:9077-9084.

Faissner A, Teplow DB, Kubler D, Keilhauer G, Kinzel V, Schachner M (1985) Biosynthesis and membrane topography of the neural cell adhesion molecule L1. EMBO J 4:3105-3113.

Fransen E, Lemmon V, van Camp G, Vits L, Coucke P, Willems PJ (1995) CRASH syndrome: clinical spectrum of corpus callosum hypoplasia, retardation, adducted thumbs, spastic paraparesis and hydrocephalus due to mutations in one single gene, L1. Eur J Hum Genet 3:273-284.

Fransen E, van Camp G, D'Hooge R, Vits L, Willems PJ (1998) Genotypephenotype correlation in L1 associated diseases. J Med Genet 35:399-404.

Frederick JM, Krasnoperova V, Hoffmann K, Church-Kopish J, Ruther K, Howes K, Lem J, Baehr W (2001) Mutant rhodopsin transgene expression on a null background. Invest Ophthalmol Vis Sci 42:826-833.

Gow A, Southwood CM, Lazzarini RA (1998) Disrupted proteolipid protein trafficking results in oligodendrocyte apoptosis in an animal model of Pelizaeus-Merzbacher disease. J Cell Biol 140:925-934.

Haney CA, Sahenk Z, Li C, Lemmon VP, Roder J, Trapp BD (1999) Heterophilic binding of $\mathrm{L} 1$ on unmyelinated sensory axons mediates Schwann cell adhesion and is required for axonal survival. J Cell Biol 146:1173-1184.

Helenius A, Aebi M (2001) Intracellular functions of N-linked glycans. Science 291:2364-2369.

Hogan BLM, Beddington R, Constantini F, Lacy E (1994) Manipulating the mouse embryo: a laboratory manual. Cold Spring Harbor, NY: Cold Spring Harbor Laboratory.

Jensen TJ, Loo MA, Pind S, Williams DB, Goldberg AL, Riordan JR (1995) Multiple proteolytic systems, including the proteasome, contribute to CFTR processing. Cell 83:129-135.

Jouet M, Rosenthal A, MacFarlane J, Kenwrick S, Donnai D (1993) A missense mutation confirms the L1 defect in $\mathrm{X}$-linked hydrocephalus (HSAS). Nat Genet 4:331.

Jung M, Sommer I, Schachner M, Nave KA (1996) Monoclonal antibody O10 defines a conformationally sensitive cell-surface epitope of proteolipid protein (PLP): evidence that PLP misfolding underlies dysmyelination in mutant mice. J Neurosci 16:7920-7929.

Kallunki P, Edelman GM, Jones FS (1997) Tissue-specific expression of the 
L1 cell adhesion molecule is modulated by the neural restrictive silencer element. J Cell Biol 138:1343-1354.

Kallunki P, Edelman GM, Jones FS (1998) The neural restrictive silencer element can act as both a repressor and enhancer of L1 cell adhesion molecule gene expression during postnatal development. Proc Natl Acad Sci USA 95:3233-3238.

Kenwrick S, Watkins A, De Angelis E (2000) Neural cell recognition molecule L1: relating biological complexity to human disease mutations. Hum Mol Genet 9:879-886.

Lemmon V, Farr KL, Lagenaur C (1989) L1-mediated axon outgrowth occurs via a homophilic binding mechanism. Neuron 2:1597-1603.

Mahadeva R, Stewart S, Bilton D, Lomas DA (1998) Alpha-1 antitrypsin deficiency alleles and severe cystic fibrosis lung disease. Thorax 53:1022-1024.

Meech R, Kallunki P, Edelman GM, Jones FS (1999) A binding site for homeodomain and Pax proteins is necessary for $\mathrm{L} 1$ cell adhesion molecule gene expression by Pax- 6 and bone morphogenetic proteins. Proc Natl Acad Sci USA 96:2420-2425.

Michaelis RC, Du YZ, Schwartz CE (1998) The site of a missense mutation in the extracellular Ig or FN domains of L1CAM influences infant mortality and the severity of X linked hydrocephalus. J Med Genet 35:901-904.

Michelson P, Hartwig C, Schachner M, Gal A, Veske A, Finckh U (2002) Missense mutations in the extracellular domain of the human neural cell adhesion molecule L1 reduce neurite outgrowth of murine cerebellar neurons. Hum Mutat, in press.

Miura M, Asou H, Kobayashi M, Uyemura K (1992) Functional expression of a full-length cDNA coding for rat neural cell adhesion molecule L1 mediates homophilic intercellular adhesion and migration of cerebellar neurons. J Biol Chem 267:10752-10758.

Moos M, Tacke R, Scherer H, Teplow D, Fruh K, Schachner M (1988) Neural adhesion molecule $\mathrm{L} 1$ as a member of the immunoglobulin superfamily with binding domains similar to fibronectin. Nature 334:701-703.

Moulding HD, Martuza RL, Rabkin SD (2000) Clinical mutations in the L1 neural cell adhesion molecule affect cell-surface expression. J Neurosci 20:5696-5702.

Needham LK, Thelen K, Maness PF (2001) Cytoplasmic domain mutations of the L1 cell adhesion molecule reduce L1-ankyrin interactions. J Neurosci 21:1490-1500.

Olsson JE, Gordon JW, Pawlyk BS, Roof D, Hayes A, Molday RS, Mukai S, Cowley GS, Berso EL, Dryja TP (1992) Transgenic mice with a rhodopsin mutation (Pro23His): a mouse model of autosomal dominant retinitis pigmentosa. Neuron 282:266-270.

Parodi AJ (2000) Protein glycosylation and its role in protein folding. Annu Rev Biochem 69:69-93.
Rolf B, Kutsche M, Bartsch U (2001) Severe hydrocephalus in L1-deficient mice. Brain Res 891:247-252.

Sadoul K, Sadoul R, Faissner A, Schachner M (1988) Biochemical characterization of different molecular forms of the neural cell adhesion molecule L1. J Neurochem 50:510-521.

Sadoul R, Kirchhoff F, Schachner M (1989) A protein kinase activity is associated with and specifically phosphorylates the neural cell adhesion molecule L1. J Neurochem 53:1471-1478.

Schneider AM, Griffiths IR, Readhead C, Nave KA (1994) Dominantnegative action of the jimpy mutation in mice complemented with an autosomal transgene for myelin proteolipid protein. Proc Natl Acad Sci USA 92:4447-4451.

Takeda Y, Asou H, Murakami Y, Miura M, Kobayashi M, Uyemura K (1996) A nonneuronal isoform of cell adhesion molecule L1: tissue-specific expression and functional analysis. J Neurochem 66:2338-2349.

Thelen K, Kedar V, Panicker AK, Schmid RS, Midkiff BR, Manness PF (2002) The neural cell adhesion molecule L1 potentiates integrin-dependent cell migration to extracellular matrix proteins. J Neurosci 22:4918-4931.

Van Camp G, Fransen E, Vits L, Raes G, Willems PJ (1996) A locus-specific mutation database for the neural cell adhesion molecule L1CAM (Xq28). Hum Mutat 8:391.

Ward CL, Kopito RR (1994) Intracellular turnover of cystic fibrosis transmembrane conductance regulator. Inefficient processing and rapid degradation of wild-type and mutant proteins. J Biol Chem 269:25710-25718.

Ward CL, Omura S, Kopito RR (1995) Degradation of CFTR by the ubiquitin-proteasome pathway. Cell 83:121-127.

Weller S, Gartner J (2001) Genetic and clinical aspects of X-linked hydrocephalus (L1 disease): mutations in the L1CAM gene. Hum Mutat $18: 1-12$.

Wu Y, Whitman I, Molmenti E, Moore K, Hippenmeyer P, Perlmutter DH (1994) A lack in intracellular degradation of mutant alphal-antitrypsin correlates with the liver disease phenotype in homozygous PiZZ alpha1antitrypsin deficiency. Proc Natl Acad Sci USA 91:9014-9018.

Yamasaki M, Thompson P, Lemmon V (1997) CRASH syndrome: mutations in L1CAM correlate with severity of the disease. Neuropediatrics 28:175-178.

Zhao X, Yip PM, Siu CH (1998) Identification of a homophilic binding site in immunoglobulin-like domain 2 of the cell adhesion molecule L1. J Neurochem 71:960-971.

Zisch AH, Stallcup WB, Chong LD, Dahlin-Huppe K, Voshol J, Schachner M, Pasquale EB (1997) Tyrosine phosphorylation of L1 family adhesion molecules: implication of the Eph kinase Cek5. J Neurosci Res 47:655665. 